\title{
RESEARCH PAPER \\ Exploratory analysis of foreign markets for Spanish organic wines
}

\author{
Fernando J. Fuentes-García,Ana B. Cosano-Carrillo, and Sandra M. \\ Sánchez-Cañizares
}

Universidad de Córdoba, Cátedra Extenda de Internacionalización. c/Puerta Nueva s/n - 14071 Córdoba (Spain).

\begin{abstract}
F.J.Fuentes-García,A.B. Cosano-Carrillo, and S.M. Sánchez-Cañizares. 2015. Exploratory analysis of foreign markets for Spanish organic wines.Cien. Inv. Agr. 42(2): 139-152. Because of the significant growth that the Spanish organic vineyard sector is experiencing, this paper's objective is to analyze and describe potential international markets for the exportation of organic wine. The methodology followed classifies the potential international markets for exportation in accordance with secondary data concerning the countries participating in this research, specific variables relating to the product under study and the use of statistical quality filters. The different types of quantitative variables that influence consumption are studied using k-median clustering analysis. According to the systematic analysis approach developed, the most favorable markets for Spanish organic wine exportation are the United States, China, Canada and certain European countries with a relevant commercial relationship with Spain (France, United Kingdom, Germany and Switzerland).
\end{abstract}

Key words: Eco-agriculture, organic wine, international trade, priority market

\section{Introduction}

The search for a healthier and more natural diet and the growing concern over the sustainability of certain agricultural production methods is the driving force behind the worldwide increase in demand for organic produce.

In Spain, 1.8 million hectares (nearly 7,000 square miles) are devoted to organic agriculture, representing the fifth position in the global wine production scene and the first position within the European Union (Ministerio de Agricultura,

Received June 18, 2014. Accepted March 15, 2014. Corresponding author: fernando.fuentes@uco.es
2011). Most of this organic produce is sold in international markets. Another driving force behind this development is policy support, particularly from the EU Common Agricultural Policy (CAP), which allows the use of less aggressive agricultural practices and promotes organic agricultural production.

This paper's objective is to analyze and describe potential international markets for the exportation of organic wine from the Spanish organic vineyard sector. The purpose herein is to provide a comprehensive overview of the global organic produce market and to elucidate how the increasing trend in obtaining a type of organic certification can provide added value for export purposes. For 
this particular paper, we will adopt a classification approach according to the degree of suitability of international markets for exporting Spanish organic wine. This research is essential prior to tackling international markets for a more successful and efficient use of the producers' resources.

The article is structured as follows. First, it reviews the literature on organic agriculture, statistics about vineyard organic markets and international markets. This article then provides a market valuation methodology. Finally, the most salient results are discussed, and conclusions regarding the most favorable markets for Spanish organic wine exportations are provided.

\section{Materials and methods}

\section{Theoretical framework}

For the purpose of analyzing the organic produce market, we will start by defining the concept of "organic agriculture" and "organic consumer". Subsequently, we will briefly analyze the latest available statistics on organic produce supply and demand, focusing on the global and the Spanish viticulture scene. Finally, this section will include a description of the approach used for the classification of potential organic wine markets for export purposes according to suitability and competitive strengths.

Organic agriculture and organic consumer. The definition of organic agriculture is conflicting, given the existing multiple different designations as well as with the lack of knowledge regarding this agricultural practice and several related clichés.

European Union (EU) Council Regulation (EEC) No. 2092/91 on the organic production of agricultural products and indications referring therein to agricultural products and foodstuffs was published in 1991. It was repealed by the Council Regulation (EC) No 834/2007 of 28 June 2007 on organic production and labeling of organic products, which defines organic production as "an overall system of farm management and food production that combines best environmental practices, a high level of biodiversity, the preservation of natural resources, the application of high animal welfare standards and a production method in line with the preference of certain consumers for products produced using natural substances and processes." Similarly, this EU Regulation establishes that the terms ecological, biodynamic and organic and their derivatives or diminutives, such as 'bio' and 'eco', alone or combined, are synonyms and can be used indistinctly.

A "green consumer" or "ecological consumer" can be defined as an individual who is mindful of environment-related issues and obligations and, therefore, solely purchases products that have the smallest impact possible on the environment (Chamorro, 2001).

Recently, governments, consumers and companies have become increasingly aware of environmental issues and the dangers associated with irresponsible consumption. The growing consumer concern over these matters has led to an increased demand for organic products and recycling. The subsequent significant increase in organic supply is mainly because of the EU subsidies for organic producers, the saturation of the current food market and the growing concern over environment and food safety (Fraj and Martínez, 2004).

Regarding production, according to the latest FiBL/ IFOAM survey on organic agriculture worldwide 2014 (data as of the end of 2012), there is a total of 37.5 million hectares of organic agricultural land worldwide (including conversion areas). The countries with the largest increase in organic farmland are France ( +0.17 million hectares), Poland $(+0.15$ million hectares $)$ and Spain $(+0.13$ million hectares).

In absolute terms, the countries representing the highest number of organic farmland hectares are Australia, Argentina and the United States. Spain 
holds the fifth position with 1.8 hectares (Figure 1). The farmland devoted to organic production is mainly used for the large-scale cultivation of cereal and green fodder from arable lands. Next in importance are coffee, olives, oilseeds and protein crops.

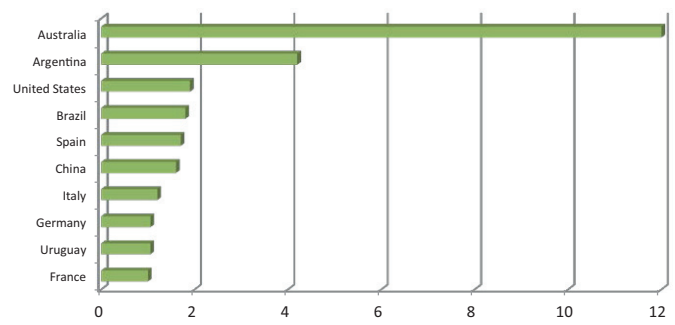

Figure 1. Countries with the greatest organic farmland surface area in 2012 (Million hectares). Source: FiBLIFOAM (2014) and data compiled by the author.

Nevertheless, although in recent years many countries have observed a significant increase in organic production, in those areas, the demand for such products has not increased at the same pace. There are a high number of "organic consumers" in developed countries. Spain, for instance, is experiencing an increase in the area of organic agricultural land although the Spanish productive structure is not as well developed as it is in other countries. This provides the organic producers with a broad scope of action to improve, diversify and adapt their production to the current consumers' demands (Martín, 2010).

\section{Organic vineyard market}

According to data from the FiBL/IFOAM survey 2012, the global organic market size is $€ 64,000$ million, and the demand for such products is expected to continue to grow in the future. The market research company, Organic Monitor (Organic Monitor is a British Research and Business Consulting company specializing in organic products. http://www.organicmonitor.com), declared that estimated worldwide organic food and drink market sales in 2010 were $€ 44,500$ million. In a decade, the sales have tripled, achieving $€ 13,500$ million in 2000. After a deceleration in sales growth caused by the financial crisis in 2008, the volume of sales has continued to increase at a healthy pace. According to some market research studies, the market will continue to increase in the future, likely attaining $€ 83$ billion in 2015 .

The main organic markets are in the US and the European Union. The FiBL-IFOAM report 2013 states that, in these markets, the strong growth rate has remained steady and the growth prospects remain optimistic. The value of the European market grew by approximately six percent. Healthy growth has continued in countries such as Germany, France, the Netherlands and Finland. Certain country markets have shown minimal, if any, growth because of poor economic conditions (Southern European countries in particular). The volumes of consumption per capita have increased at the same pace as awareness of the environment and of the importance of a healthy diet. This trend has grown both in countries with an organic tradition and in more traditional countries.

Statistics on production and demand for organic wine are not very reliable. This is an important issue because both conventional and organic wines are under the same tariff classification. According to the FiBL-IFOAM survey (FiBLIFOAM, 2014), in 2012 (the latest year for which there is data), the organic vineyard surface area grew to 284,265 hectares, 95,795 hectares more than in 2009 .

Figure 2 shows the worldwide distribution of organic vineyard surface area. A striking European leadership can be noted. Since 2009, and after snatching the first position from Italy, Spain leads the world ranking in organic vineyard surface area. According to data from the Ministerio de Agricultura (2011), in 2011 Spain represented a total of 81,262 hectares and 511 wine producers commercializing organic wine. Since 2008, when Spain represented 30,856 hectares, the organic agricultural surface area devoted to the cultivation of grapevines has experienced a pronounced increase. The three countries with 


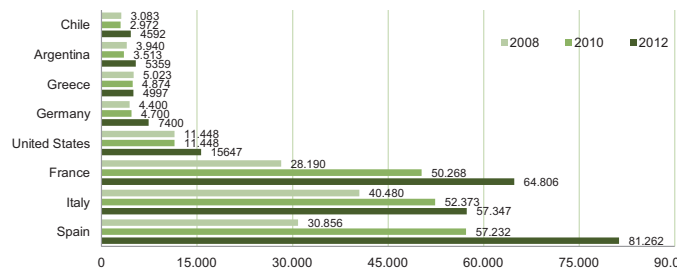

Figure 2. Organic vineyard surface area in the greatest producers (Hectares). Source: Millésime Bio (2014), IFOAM and FiBL (2014).

the largest organic vineyard surface area belong to the EU. A pronounced size increase since 2008 can be noted, particularly in Spain and France. The United States, Germany, Greece, Argentina and Chile also represent a significant number of hectares of organic farmland.

The consumption of organic wines is greater in developed countries. This trend continues to grow every year, despite the economic crisis. In their studies, Palacios et al. (2011) note that the consumption of organic wine continues to increase and particularly note the potential for growth in Canada, the USA, the majority of Europe and in Brazil. Canada's consumption growth rate is increasing by $20 \%$, which represents a business volume of US \$2 million per year. Organic wine sales in the US are approximately $\$ 26$ million every year.

Germany, France and the United Kingdom are the largest consumers of organic wine within Europe. Other countries such as Sweden, Holland, Denmark, Italy, Switzerland and Austria also show pronounced consumption growth rates.

Currently, Spain cultivates 81,262 hectares of organic vineyards (Ministerio de Agricultura, 2011), which comprise approximately $8 \%$ of the total surface area of a country that traditionally has represented the world's largest vineyard surface area. Spain is also a world leader in the volume of wine exports. However, Spain has been significantly overtaken by France and Italy in exported values. Regarding related industrial activities, Spain represented a total of 511 registered organic wineries and bottling companies in 2011.
Despite the Spanish world leadership in organic vineyard surface area, the domestic consumption of organic products is at low levels. The majority of the organic wine produced in Spain is exported to other countries. This alternative type of wine production is growing and provides a strategic opportunity and a competitive advantage versus conventional wine-a differentiation (Palacios et al., 2011).

New rules for organic wine in the European Union were published in EC Regulation 203/2012 of 8 March 2012, amending the former regulations. Until then, such wine could be solely labeled as "wine made from organic grapes". The new rules also cover wine-making practices.

Unfortunately, the statistics available regarding the exportation of organic products remain unreliable, which makes it difficult to analyze the importance of the market in terms of volume, values and main destinations. The statistics that are available are often out of date and have a low level of disaggregation. The major problem in obtaining reliable statistics is that organic products do not have their own tariff classification.

According to a report issued by the Department of Agriculture in 2011, the total organic product export volume in Spain is $€ 454$ million, and imports represented $€ 190$ million. Therefore, the export/import coverage rate is 2.39 , and the export propensity is $33.4 \%$.

Exports are mainly addressed to EU countries (particularly Germany, France, the United Kingdom, Italy, Switzerland, Belgium and the Netherlands). Imports also mainly originate from EU countries, although imports from countries outside the UE such as Brazil, Turkey, Chile, Mexico, Peru, India, China, Ecuador, Egypt and South Africa are becoming increasingly frequent.

The main countries of origin and destination of Spanish international trade in organic products, as well as the percentage over the total volume of exports and imports, are compiled in a report 
issued by the Ministerio de Medio Ambiente y Medio Rural y Marino (2010) and are displayed in Table 1.

According to the report of the Ministerio de Medio Ambiente, Rural y Marino (2010), those sectors with the largest volume of exports are: fruits and vegetables (55.6\%), olive oil (12.6\%) and wine $(5.6 \%)$. The Spanish export range has increased in recent years; however, because of its potential for growth, diversification should be encouraged.

\section{International market selection}

Douglas and Craig (1992) state that market selection is a determining decision in the internationalization process that companies are obliged to make in response to domestic market saturation, the imperatives of international competition and the loss of market share in so-called safe domestic markets. Furthermore, Galván (2003) examined the existing literature on international market selection and market entry strategies, concluding that an adequate choice must be based on the evaluation of opportunities and threats, costs and benefits (Anderson and Gatignon, 1986; Ekeledo and Sivakumar, 1998). Finally, the abovementioned opposite variables relating the countries to be evaluated are referred to as "potential demand" and "trade barriers" in the model presented by Papadopoulos et al. (2002).
The normative literature describes the process of an international market entry decision as a rational response to market conditions that should be based on objective information gathered on a systematic basis through market research studies (Rott, 1994; Young et al., 1989).

For Galván (2003), the market selection process should be derived from a structured and official decision-making process in which the decisionmaker needs to identify all the objective criteria that could be used to evaluate the different alternatives. The appropriate types of indicators for international market selection were suggested for the first time in the 1960s (Conners, 1960; Bartels, 1963).

In the $1980 \mathrm{~s}$, certain authors criticized the systematic approach to international market selection and supported a decision-making process based on secondary data indicators (Papadopoulos et al., 2002). Another issue relating to the systematic approach to international market selection is that it is not specific to a certain type of product. Some researchers attempted to correct that mistake by incorporating the use of product specific variables (Moyer, 1968; Samli, 1977). Finally, other researchers have suggested the introduction of qualitative data to the above-noted approach to modify the rigidity and potential expiry of secondary data (Green and Allaway, 1985).

Table 1. Countries of origin and destination of Spanish organic product international trade.

\begin{tabular}{lccc}
\hline Countries of destination & \% Exportation & Countries of origin & \% Exportation \\
\hline Germany & 18 & Netherlands & 25 \\
France & 14 & France & 15 \\
United Kingdom & 10.5 & Austria & 10 \\
Italy & 7.0 & Germany & 5 \\
Switzerland & 6.5 & Italy & 5 \\
Netherlands & 6.5 & Belgium & 5 \\
Belgium & 6 & Brazil & 5 \\
Denmark & 5.5 & Turkey & 5 \\
United States & 4.5 & Chile & 5 \\
Japan & 3.5 & India & 5 \\
Other countries & 18.0 & Other countries & 15 \\
\hline
\end{tabular}

Source: Ministerio de Medio Ambiente, Rural y Marino (2010). 
More recently in Spain, a new approach to identify priority markets for export purposes on a systematic basis by using both secondary data and product specific variables has been developed by the Subdirección General de Análisis y Estrategia (2005).

\section{Statistical analysis}

Using the above-noted work by the Subdirección General de Análisis y Estrategia (2005) and that by Lanzas y Moral (2007) as a starting point, our methodology offers a systematic approach to the evaluation of priority markets for export purposes considering secondary data, specific variables relating to the product under study (organic wine) and the use of statistical quality filters. The different types of quantitative variables that influence consumption are studied using clustering analysis; this will be the focus of our analysis adapted to organic wine. For the selection of the indicators used in this research, a group of experts in international marketing and wine sector professionals were consulted. Figure 3 shows our proposed model.

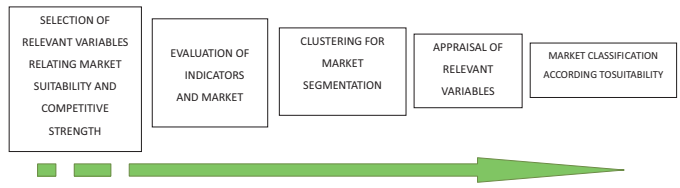

Figure 3. Model proposed for marked evaluation.

Once the market data matrix was obtained, our objective was to perform a cluster analysis to establish clusters of countries reflecting different market potential levels for organic wines.

Table 2 shows an overview of the selected indicators that will be used throughout this paper.

Indicators are classified into two main groups, Market Suitability and Competitive Strength, which are further subdivided into groups. The group Market Suitability is essential because it determines the short-term and middle-term sales volume and evaluates the risk of conducting business in that country as well as its associated additional costs.

In our research, the market size is measured through GDP in terms of estimated purchasing power parity for 2012. That method allows comparison of the different countries' financial capacity, eliminating the distortion created by the different exchange rates. The population is also an important indicator because it allows us to know the number of potential wine consumers in every country, which will enable us to reach more consumers with the same level of effort.

Another indicator used in this research to measure the size of the market is the countries' wine consumption rate, which allows us to determine whether the demand for wine is sufficiently high to justify devoting our efforts to a certain country. The wine consumption rate is the indicator used to obtain the list of countries to be evaluated. For this study, we have selected the 67 countries with the highest wine consumption rates (not including Spain, which represents the seventh position, or Afghanistan, Equatorial Guinea and Turkmenistan, which lack available statistical data). Finally, we will use the country's wine import proportion of global imports (Statistical Information on international trade in this section was derived from the International Trade Center (www.intracen.org), which reflects the country's disposition to import wine. That information is important because for a country to be interesting businesswise, in addition to showing high levels of consumption, it needs to be importing the wine that is consumed by its population.

Second, the market growth will be measured considering the estimated average growth of GDP for the period 2012-2015, the annual evolution of the wine imports proportion for the 2007-2011 period and the country's environmental performance. The environmental performance index (EPI) measures the ecological performance of the countries. In our study, the EPI is used to provide information on a country's level of environmental concern, 
Table 2. Indicators involved in the selection process of international markets for organic wine.

\begin{tabular}{|c|c|c|}
\hline Subgroup & Indicators & Type of indicators \\
\hline \multirow[t]{5}{*}{ Market Size } & GDP & General Secondary \\
\hline & Population & General Secondary \\
\hline & GDP per capita & General Secondary \\
\hline & Wine consumption rate & Specific Secondary \\
\hline & Share of total imports & Specific Secondary \\
\hline \multirow[t]{3}{*}{ Market Growth } & Estimated GDP growth & General Secondary \\
\hline & Evolution of wine imports share & Specific Secondary \\
\hline & Environmental performance & Specific Secondary \\
\hline \multirow{2}{*}{$\begin{array}{l}\text { Commercial and Political } \\
\text { Risk }\end{array}$} & Ease of doing business & General Secondary \\
\hline & Country risk & General Secondary \\
\hline \multirow[t]{2}{*}{ Other Factors } & Geographical distance & General Secondary \\
\hline & Strategic commercial interest & Quality Filter \\
\hline \multirow[t]{2}{*}{ Spanish Position } & Spanish share of wine imports & Specific Secondary \\
\hline & Evolution of the Spanish wine imports share & Specific Secondary \\
\hline Contribution to Exports & Percentage of Spanish exports to the country & Specific Secondary \\
\hline Export Dynamism & Evolution of Spanish exports to the country & Specific Secondary \\
\hline Other Factors & Common cultural factors & Quality Filter \\
\hline
\end{tabular}

Source: Data compiled by author from Lanzas and Moral (2007) and experts' opinion.

${ }^{2}$ Population estimated by the CIA in July 2012 in The World Factbook.

${ }^{3} \mathrm{GDP}$ per capita, as well as the remaining statistical information relating to GDP in this section was obtained from the FMI: World Economic Outlook Database October 2012 (www.imf.org).

which shows how willing the population is to purchase ecological products and how supportive the government is via regulations.

The commercial and political risk is measured, on the one hand, using a ranking detailed by Doing Business, which measures the ease of doing business in a particular country and, on the other hand, using the risk-country evaluation made by the Coface Group. Finally, the geographical distances measured in a straight line from Spain to the capital of each country and strategic commercial interest are also considered as complementary factors. The strategic commercial interest is used to measure trade barriers and will be measured by analyzing the country's membership in international organizations. Special value is accorded if the country is a member of the EU or if the EU has signed bilateral commercial treaties (abbreviation $\mathrm{AB}$ ) or regional treaties (abbreviation AR) with that country. Belonging to the WTO and the OECD are also valued. Finally, the abbreviation ECO will be accorded when the organic product certification in a certain country is similar to that of Spain.

The second group, Competitive Strength, measures the sales position of Spanish companies in a certain country as well as the common cultural characteristics between both countries. To obtain the Spanish position in the country, the Spanish wine import proportion in 2011 as well as its evolution over the period 2007-2011 will be used. Other indicators are the percentage of Spanish exports to the country and the evolution of the percentage of Spanish exports for the 2007-2011 period.

Finally, the cultural similarities between Spain and the countries in which organic wine exports are to be targeted are included within the Competitive Strength group. Cultural similarities are assessed by using the classification in eight 
cultural groups detailed by Ronen and Shenkar (1985) as well as two additional cultural groups added by Peng et al. (2000).

\section{Market categories}

First, a valuation table of countries was created with the values of the indicators used for selecting priority markets for the export of organic wine among all the countries valued.

Subsequently, in a second phase, data were divided into different categories according to their similarities to obtain homogeneous groups. The different types of quantitative variables were obtained by using the k-medians clustering analysis method because it is the most appropriate when there is a high number of cases. For the purpose of this paper, the indicators were established, each with a designated value between 0 and 5 , with 0 being the most unfavorable value and 5 the best-case scenario.

For qualitative indicators, we followed a more subjective methodology. Indicator 10, which measures the country risk, is determined as follows: level A1 (value 5), level A2 (value 4), level A3 (value 3), level A4 (value 2), level B (value 1) and finally, levels $\mathrm{C}$ and D (value 0).

The values for Variable 12, which measures the strategic commercial interest, are determined as follows: membership in the EU, 2 points; Bilateral Treaty (AB) or Regional Treaty (AR) with the EU, 1 point. Furthermore, an additional point is added if the country is a member of the WTO or the OECD. Another additional point is accorded to those countries with organic certification equivalent to that of Spain. Therefore, a country obtains the highest value (5) when it belongs to the EU (value 2), when it is a member of the WTO (value 1), when it is a member of the OECD and when its organic certifications are equivalent to that of Spain.
Finally, the indicator measuring the common cultural factors will be determined as follows: Latin Europe (value 5), Latin America (value 4), Germanic countries (value 3), Anglo-Saxon countries (value 3), Nordic countries and Eastern Europe (value 2), Far and Near East and Independent countries (value 1), Arab countries and Sub-Saharan Africa (value 0).

Once the data matrix was obtained (Table 3) using the previous tables and the SPSS data editor, a k-medians clustering analysis was performed in four clusters.

\section{Results}

\section{Clusters analysis}

In the process, variables number 11 (geographical distance) and 13 (Spanish quota in imports of wine from the country) were removed because they did not generate significant differences between clusters according to the associated ANOVA test. The results after this adaptation are presented in Table 3.

The four clusters obtained can be interpreted as follows:

- Cluster 1: Countries with high environmental performance and broad strategic interest. These countries also receive medium-high scores on wine consumption, percentage of Spanish wine exports directed to these territories and common cultural factors. Their scores are reduced in the ease of doing business, the estimated GDP growth and evolution of the proportion of wine imports. This cluster includes the following countries: France, Germany, Italy, the USA and the UK.

- Cluster 2: Countries with a large population and high GDP growth, but very low GDP per 
Table 3. Center of clusters.

\begin{tabular}{lcccc}
\hline & \multicolumn{3}{c}{ Cluster } \\
\cline { 2 - 5 } Indicators & 1 & 2 & 3 & 4 \\
\hline GDP & 2.60 & 3.50 & 0.32 & 0.25 \\
Population & 1.40 & 4.50 & 0.04 & 0.25 \\
GDP per capita & 2.60 & 0.00 & 2.50 & 0.72 \\
Wine consumption rate & 3.80 & 1.00 & 0.50 & 0.25 \\
Share of total imports & 3.20 & 1.00 & 0.57 & 0.13 \\
Estimated GDP growth & 0.80 & 4.50 & 1.29 & 2.53 \\
Evolution of wine imports share & 0.80 & 3,50 & 1.29 & 2.56 \\
Environmental performance & 4.40 & 0.50 & 3.82 & 2.31 \\
Ease of doing business & 0.60 & 3.50 & 0.82 & 2.47 \\
Country risk & 3.40 & 3.00 & 3.54 & 1.28 \\
Strategic commercial interest & 4.80 & 1.50 & 4.36 & 1.97 \\
Spanish share of wine imports & 1.20 & 3.50 & 1.29 & 2.31 \\
Evolution of Spanish wine imports share & 3.80 & 1.00 & 0.39 & 0.06 \\
Evolution of Spanish exports to the country & 1.80 & 3.50 & 1.89 & 2.69 \\
Common cultural factors & 3.80 & 1.00 & 2.46 & 1.63 \\
\hline
\end{tabular}

capita and environmental performance. Wine consumption, rates of wine exports to the country and the proportion of imports of this product are reduced, such that commercial interest also shows a low value. China and India fall within this cluster.

- Cluster 3: Countries in which the strategic commercial interests are noticed, followed by their environmental performance. However, these countries present a very small population, poor GDP, and reduced wine consumption and imports, such that Spanish exports to these countries are practically irrelevant. This larger group contains the following countries: Australia, Austria, Belgium, Bulgaria, Canada, Chile, Czech Republic, Denmark, Estonia, Finland, Greece, Hungary, Ireland, Japan, Latvia, Luxembourg, Netherlands, New Zealand, Norway, Poland, Portugal, Singapore, Slovakia, Slovenia, South Korea, Sweden, Switzerland, and Taiwan.

- Cluster 4: Countries with no relevant valuations in any of the indicators because they are always below 3 points. However, these countries present better results in the evolution of wine imports, the ease of doing business, the evolution of the Spanish quota in wine imports, and the evolution of Spanish wine exports to the country in the cluster rather than countries in clusters 1 and 3. However, GDP, population, and actual percentage of exports of Spanish wine targeted to countries in this group are very limited. In this cluster are Albania, Algeria, Angola, Argentina, Belarus, Brazil, Colombia, Croatia, Cyprus, Ghana, Ivory Coast, Kazakhstan, Hong Kong, Lebanon, Lithuania, Macedonia, Malaysia, Mexico, Moldova, Morocco, Nigeria, Paraguay, Peru, Romania, Russia, South Africa, Tunisia, Turkey, Ukraine, United Arab, Emirates Uruguay, and Uzbekistan.

\section{Market suitability and competitive strength}

Once the data matrix was obtained using the aforementioned methodology and the SPSS data editor analysis was performed, the indicators of both groups, Market Suitability and Competitive Strength, were calculated. Different weights were 
accorded to the different sub-groups based on their level of importance. All of these data were evaluated considering the opinion of experts. The calculation was performed according to the following formula:

Market Suitability $=0.44 \times$ Market Size +0.33 $\times$ Market Growth $+0.13 \times$ Commercial and Political Risk $+0.1 \times$ Other factors $\quad$ Eq. 1

Competitive Strength $=0.36 \times$ Spanish position in the country $+0.27 \times$ Contribution to total exportation $+0.20 \times$ Export Dynamism +0.17 $\times$ Other factors $\quad$ Eq. 2

Strategic groups for organic wine exportation

Countries were divided into four groups, the dividing lines between each group being the Market Suitability average value (6.22) and the Competitive Strength average value (1.87).

Groups were established as follows:
- Group 1 includes countries whose Market Suitability and Competitive Strength are higher than the average, that is, the most suitable destinations for Spanish organic wine exportation.

- Group 2 encompasses countries whose Market Suitability is higher than the average but in which the Spanish Competitive Strength is lower than the average.

- In Group 3, countries have a Market Suitability level that is lower than the average but a higher-than-the-average level of Spanish Competitive Strength.

- Finally, Group 4 includes those countries with the lowest Market Suitability and Competitive Strength levels, that is, the less suitable countries for Spanish organic wine exportation.

Figure 4 and Table 4 shows the abovementioned classification of countries into 4 groups.

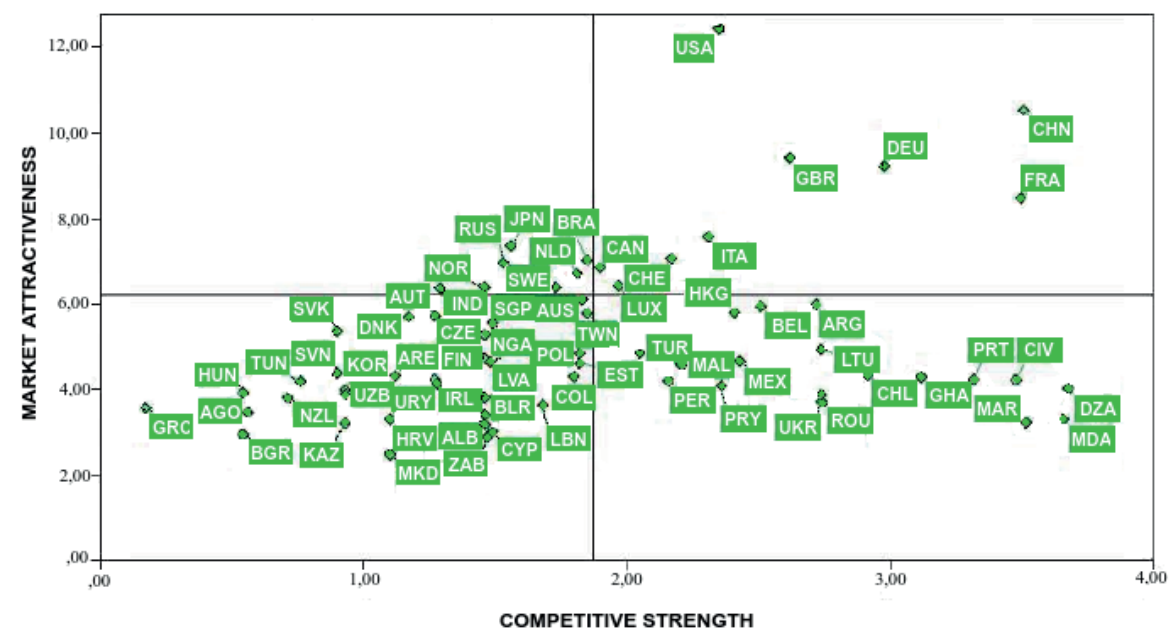

AGO: Angola; ALB: Albania; ARE: United Arab Emirates; ARG: Argentina; AUS: Australia; AUT: Austria; BEL: Belgium; BGR: Bulgaria; BLR: Belarus; BRA: Brazil; CAN: Canada; CHE: Switzerland; CHL: Chile; CHN: China; CIV: Côte d'Ivoire; COL: Colombia; CYP: Cyprus; CZE: Czech Republic; DEU: Germany; DNK: Denmark; DZA: Algeria; EST: Estonia; FIN: Finland; FRA: France; GBR: United Kingdom; GHA: Ghana; GRC: Greece; HKG: Hong Kong; HUN: HUngary; IND: India; IRL: Ireland; ITA: Italy; JPN: Japan; KAZ: Kazakhstan; KOR: Republic of Korea; LBN: Lebanon; LTU: Lithuania; LUX: Luxembourg; LVA: Latvia; MAL: Malaysia; MDA: Republic of Moldova; MEX: Mexico; MKD: The Former Yugoslav Republic of Macedonia; MAR: Morocoo; NGA: Nigeria; NLD: Netherlands; NOR: Norway; NZL: New Zealand; PER: Peru; POL: Poland; PRT: Portugal; PRY: Paraguay; ROU: Romania; RUS: Russian Federation; SGP: Singapore; SVK: Slovakia; SVN: Slovenia; SWE: Sweden; TUN: Tunisia; TUR: Turkey; TWN: Taiwan, Province of China; UKR: Ukraine; URY: Uruguay; USA: United States; UZB: Uzbekistan; ZAF: South Africa

Figure 4. Strategic Groups for organic wine export. Source: Data compiled by the author. 
Table 4. Strategic Groups for organic wine exportation

\begin{tabular}{|c|c|c|c|}
\hline \multirow{3}{*}{$\mathrm{MS} \geq \mathrm{MS}$ average } & \multicolumn{2}{|c|}{$\begin{array}{c}\text { CS }<\text { CS average } \\
\text { GROUP } 2 \\
\text { HIGH SUITABILITY } \\
\text { WEAK POSITION OF SPAIN }\end{array}$} & $\begin{array}{c}\text { CS } \geq \text { CS average } \\
\text { GROUP } 1 \\
\text { MAXIMUM SUITABILITY }\end{array}$ \\
\hline & $\begin{array}{l}\text { Brazil } \\
\text { India } \\
\text { Japan } \\
\text { Norway }\end{array}$ & $\begin{array}{l}\text { The Netherlands } \\
\text { Russia } \\
\text { Sweden }\end{array}$ & $\begin{array}{ll}\text { Germany } & \text { Italy } \\
\text { Canada } & \text { Luxemburg } \\
\text { China } & \text { United Kingdom } \\
\text { United States } & \text { Switzerland } \\
\text { France } & \end{array}$ \\
\hline & $\begin{array}{r}\text { GR } \\
\text { LOWEST }\end{array}$ & $\begin{array}{l}\text { UP } 4 \\
\text { IITABILITY }\end{array}$ & $\begin{array}{c}\text { GROUP } 3 \\
\text { LOW SUITABILITY } \\
\text { GOOD POSITION OF SPAIN }\end{array}$ \\
\hline MS $<$ MS average & $\begin{array}{l}\text { Albania } \\
\text { Angola } \\
\text { Australia } \\
\text { Austria } \\
\text { Belorussia } \\
\text { Bulgaria } \\
\text { Cyprus } \\
\text { Colombia } \\
\text { South Korea } \\
\text { Croatia } \\
\text { Denmark } \\
\text { United Arab Emirates } \\
\text { Slovakia } \\
\text { Slovenia } \\
\text { Estonia } \\
\text { Finland } \\
\text { Greece } \\
\text { Hungary } \\
\text { Ireland }\end{array}$ & $\begin{array}{l}\text { Kazakhstan } \\
\text { Latvia } \\
\text { Lebanon } \\
\text { Macedonia } \\
\text { Nigeria } \\
\text { New Zealand } \\
\text { Poland } \\
\text { Czech Republic } \\
\text { Singapore } \\
\text { South Africa } \\
\text { Taiwan } \\
\text { Tunisia } \\
\text { Uruguay } \\
\text { Uzbekistan }\end{array}$ & $\begin{array}{l}\text { Algeria } \\
\text { Argentina } \\
\text { Belgium } \\
\text { Chile } \\
\text { Ivory Coast } \\
\text { Ghana } \\
\text { Hong Kong } \\
\text { Lithuania } \\
\text { Malaysia } \\
\text { Morocco } \\
\text { Mexico } \\
\text { Moldavia } \\
\text { Peru } \\
\text { Portugal } \\
\text { Romania } \\
\text { Turkey } \\
\text { Ukraine }\end{array}$ \\
\hline
\end{tabular}

\section{Discussion}

In fragmented markets and markets saturated with excess supply, as the wine market currently is, product differentiation is an attractive alternative for positioning an organic product; it combines high added value while respecting the environment. Spain has recently attained global leadership in organic farming, and wine is an easy to transport product. Thus, it is necessary to find new markets for the growing organic production.

The scarcity of statistics on trade and foreign markets represent one difficulty in exploring foreign markets. Unfortunately, there is no separate tariff convention for organic products. Simultaneously, there is a lack of accurate information on the ecological dimension of potential consumers in different countries, complicating the targeting efforts in organizations. According to Porter (1991), in international markets, the nations, not the companies, are competitors; however, it is useful to begin to identify the countries with the greatest potential for success. In this situation, an exploratory analysis allows the commencement of country-market research and formulation of the hypothesis regarding markets with the greatest potential. This paper has used a methodology to combine expert opinion as well as qualitative, quantitative and filter market data that provide a preview of the priority markets to approach.

According to the systematic analysis approach developed through this paper, we can conclude by stating that the most favorable markets for Spanish organic wine exportations are the two great powers (United States and China), Canada and certain European countries with a relevant commercial relation with Spain (France, United Kingdom, Germany, and Switzerland). All of these countries also represent high positions in the ranking of organic product consumption. Finally, 
there is also an interesting group of countries for organic wine exportation in which Spain still holds a weak position. These countries are Brazil, Sweden, Norway and certain other countries with a high level of suitability.

These results agree with the mature organic markets in Europe proposed by Schmid et al. (2007). For organic wines specifically, Rodriguez (2003) supports the UK Germany, Holland, Belgium and Japan as better markets, but questions the US market because of increasing local production.

Different improvements can be proposed for the model used in this paper. Thus, certain variables can be included for the following topics: the current saturation of markets for organic products important to local production and trade barriers or the barriers to reaching the distribution channels (these are important in this type of product according to Hernández, 2014). Conversely, it would be desirable to obtain further knowledge of market segmentation for these products (Mora et al., 2010) and the attributes that customers value in each territory (Brugarolas et al., 1997).

It is necessary to note that this study has been performed for a certain period of time, and its results may vary when an update of the data is attempted. To obtain a different classification, the methodology followed throughout the study may be used differently by modifying the different weights assigned to the variables. Additionally, the fact that the countries located closer to the center of the graph (closer to both averages) may change groups easily should be considered. Certain of these countries can be interesting from a business perspective, although the market's opening may be more expensive, riskier and take longer.

Finally, it should be noted that, after selection of an international target market, organic producers must assess their know-how and their own financial and organizational capabilities given that these also condition the strategy to access foreign markets.

\section{Resumen}

F.J. Fuentes-García, A.B. Cosano-Carrillo y S.M. Sánchez-Cañizares. 2015. Análisis exploratorio de los mercados extranjeros para los vinos ecológicos españoles. Cien. Inv. Agr. 42(2): 139-152. En este trabajo se analizan los mercados exteriores para la exportación de los vinos ecológicos ante el importante incremento que está experimentando el viñedo ecológico español (actualmente más de un tercio del total mundial). Se utiliza una metodología que sistematiza la valoración de mercados de exportación a partir de datos secundarios de los países a valorar, variables específicas del producto objeto de estudio y filtros cualitativos. Tras un análisis cluster de k-medias y el enfoque sistemático desarrollado, los mercados más favorables para las exportaciones de vinos ecológicos españoles son Estados Unidos, China, Canadá y algunos países europeos con una relación comercial relevante con España (Francia, Reino Unido, Alemania y Suiza).

Palabras clave: Comercio internacional, eco-agricultura, mercado prioritario, vino orgánico. 


\section{References}

Anderson, A., and H. Gatignon. 1986. Modes of Foreign entry: A transaction cost analysis and propositions. Journal of International Business Studies 17(3):1-26.

Barnes, W.N. 1980.International marketing indicators. European Journal of Marketing 14(2):88136.

Bartels, R. 1963. Outline for Comparative Marketing Analysis. In: Bartels, R. (ed.). Comparation Marketing Analysis. Irwin, Homewood, IL. p. 229-308.

Brugarolas, M., L.M. Rivera, and M. Sánchez. 1997. Potencial de mercado para nuevos productos alimentarios: la producción ecológica. Investigaciones Europeas de Dirección y Economía de la Empresa3: 61-76.

Chamorro, A. 2001.El marketing ecológico. Available online at: http:/www.5campus.org/leccion/ ecomarketing (Website accessed: July 07, 2015).

Conners, R.J. 1960. World Market Potential as Developed for 3M's Overseas Operation, Dynamic Marketing for a Changing World, American Marketing Association, Chicago. p. 461-466.

Douglas, S.P., and C.S. Craig. 1992. Advances in international marketing, International Journal of Research in Marketing 9: 291-318.

Ekeledo, I. and K. Sivakumar. 1998. Foreign market entry mode choice of service firms: A contingency perspective. Journal of the Academy of Marketing Science 26: 274-292.

FiBL-IFOAM.2014.The World of Organic Agriculture - Statistics and Emerging Trends. Available online: http:/www.organic-world.net/ yearbook-2014.html (Website accessed: July 07, 2015).

Fraj, E. and E. Martínez. 2004. El consumo ecológico explicado a través de los valores y los estilos de vida. Implicaciones en la estrategia medioambiental de la empresa, Cuadernos de CC.EE.EE. 46: 33-54.

Galván, I.2003. La formación de la estrategia de selección de mercados exteriores en el proceso de internacionalización de las empresas. Tesis Doctoral, Universidad de las Palmas de Gran Canaria. España. 318 pp.
Green, R.T. and A.W. Allaway. 1985. Identification of export opportunity: A shift-share approach. Journal of Marketing 49: 83-88.

Hernández, E.A. 2014. El vino, el mercado de los orgánicos. Revista Conexión de Hospitalidad y Gastronomía 2: 25-32

Lanzas, J.R. and E. Moral. 2006. Dinámica exportadora en el sector oleícola andaluz. Identificación de mercados prioritarios. Edit. Analistas Económicos de Andalucía-Unicaja, Málaga, España. 94 pp.

Martín, V.J.2010. Alimentos ecológicos. Oferta y demanda en España. Distribución y Consumo 112: 49-60

Ministerio de Agricultura. 2011. Agricultura ecológica. Estadística 2011. Edit. Ministerio de Agricultura, Alimentación y Medio Marino. Madrid, España. 59 pp.

Ministerio de Medio Ambiente y Medio Rural y Marino. 2010. Valor y volumen de los productos ecológicos de origen nacional en la Industria Agroalimentaria española. Edit. Ministerio de Medio Ambiente y Medio Rural y Marino. Madrid, España. 182 pp.

Mora, M.G., N.S. Magner, and R. Marchant. 2010. Segmentación de Mercado de acuerdo a estilos de vida de consumidores de Vino Orgánico de la Región Metropolitana de Chile. Idesia (Arica) 28: 25-33.

Moyer, R. 1968. International market analysis. Journal of Marketing Research 3: 353-360.

Palacios, A., E. López, I. Pueyo, J. Azón, and E.I. Crespo.2011.Vino ecológico, viene para quedarse. Semana vitivinícola 3363: 2006-2009.

Papadopoulos, N., C. Hongbin, and. D.R. Thomas. 2002. Toward a tradeoff model for international market selection. International Business Review 11:165-192.

Peng, M.W., C. Hill, and D. Wang. 2000. Schumpeterian dynamics versus Williamsonian considerations: A test of export intermediary performance. Journal of Management Studies 37: 167-184.

Porter, M. 1991. Ventaja Competitiva de las Naciones. Plaza y Janés. Madrid, España. 1056 pp. 
Rodriguez, J. 2003. Análisis estratégico de la producción de vino orgánico chileno. In: Engler-Palma, A. y otros. 2003. VIII Congreso de Economistas Agrarios: Pensando laAgricultura del 2010: Desafíos, Ajustes y Política. Santiago, Chile.p. 337-346.

Ronen, S., and O.Shenkar.1985.Clustering Countries on attitudinal dimensions: A review and synthesis. Academy of Management Review 10.435-454.

Root, F.R. 1994.Entry Strategies for International Markets, Lexington Books, Nueva York, US. $324 \mathrm{pp}$.

Samli, A.C. 1972. Market potentials can be determined at the international level.Australian Journal of Market Research 7(4):85-92.
Schmid, O., G.D. Fontguyon, and P. Sans. 2007. Desarrollo del mercado de productos de la agricultura ecológica en Europa: Un análisis de sus condiciones y del papel de las iniciativas comerciales. Revista Española de Estudios Agrosociales y Pesqueros 214- 15-45.

Subdirección General de Análisis y Estrategia. 2005. Metodología de la Secretaría de Estado de Turismo y Comercio para la selección de mercados prioritarios. Boletín Económico de Información Comercio Española 2836: 3-15.

Young, S. 1989. Choosing the market entry and development strategy. International markets entry and development. Pearson Higher Education, UK. 316 pp. 